\title{
Productive potential of superior genotypes of Paspalum notatum Flügge in response to nitrogen fertilization
}

\author{
Potencial produtivo de genótipos superiores de Paspalum notatum Flügge em resposta \\ à fertilização nitrogenada
}

\begin{abstract}
MACHADO, Juliana Medianeira*1 ${ }^{1}$; DALLAGNOL, Miguel $^{2}$ (D; MOTTA, Eder Alexandre Minsk da ${ }^{2}$ (D) PEREIRA, Emerson André ${ }^{3}$ iD; BARBOSA, Marlon Risso ${ }^{2}$ (D); NEME, Jackson Camargo $^{2}$ (D); KRYCKI, Karine Cristina ${ }^{2}$
\end{abstract}

${ }^{1}$ Universidade de Cruz Alta, Centro de Ciências Agrárias e da Saúde, Cruz Alta - RS, Brasil.

${ }^{2}$ Universidade Federal do Rio Grande do Sul, Departamento de Zootecnia, Porto Alegre - RS,

Brasil. ${ }^{3}$ Universidade Regional do Noroeste do Estado do Rio Grande do Sul, Departamento de Estudos Agrários, Ijuí - RS, Brasil.

*Endereço para correspondência: julianam.machado@yahoo.com.br

\section{SUMMARY}

The Paspalum genus forms the natural pastures of the tropical and subtropical regions of America and includes several species of recognized forage potential. The aim of this study was to evaluate the influence of different levels of nitrogen fertilization on the agronomic traits and nitrogen use efficiency in superior genotypes of Paspalum notatum Flügge. Four nitrogen fertilization levels $(0,60,180$ and $360 \mathrm{~kg} \mathrm{~N} \mathrm{ha}^{-1}$ ) and nine genotypes were evaluated, six from the United States Department of Agriculture (USDA) (30N, $36 \mathrm{~N}, 48 \mathrm{~N}, 70 \mathrm{~N}, 83 \mathrm{~N}$ and $95 \mathrm{~N}$ ), collected in South America, two native genotypes of Rio Grande do Sul, Brazil (André da Rocha and Bagual) and cv. Pensacola. The experimental design was a randomized complete block in a $4 \times 9$ factorial, with four field replications. From the variability of the responses found for the agronomic traits, the genotypes $48 \mathrm{~N}$, André da Rocha and Bagual are indicated to continue in the breeding program because they reach the maximum productive efficiencies according to the doses of $\mathrm{N}$ tested. The genotype $36 \mathrm{~N}$ obtained the highest efficiency of nitrogen utilization, being biologically viable with the lowest $\mathrm{N}$ dose, equivalent of $60 \mathrm{~kg}$ of $\mathrm{N}$ $\mathrm{ha}^{-1}$.
Keywords: native species, nitrogen fertilization, genus Paspalum

\section{RESUMO}

O gênero Paspalum compõe as pastagens naturais das regiões tropicais e subtropicais da América com várias espécies de reconhecido potencial forrageiro. $\mathrm{O}$ objetivo deste estudo foi avaliar a influência de diferentes níveis de fertilização nitrogenada sobre os caracteres agronômicos e na eficiência de utilização de nitrogênio por genótipos superiores de $P$. notatum Flügge. Foram avaliados quatro níveis de fertilização nitrogenada $(0,60$, 180 e $360 \mathrm{~kg} \mathrm{~N} \mathrm{ha}^{-1}$ ) e nove genótipos, seis provenientes do United States Departament of Agriculture (USDA) $(30 \mathrm{~N}, 36 \mathrm{~N}, 48 \mathrm{~N}$, $70 \mathrm{~N}, 83 \mathrm{~N}$ e $95 \mathrm{~N}$ ), coletados na América do Sul, dois genótipos nativos do Rio Grande do Sul, Brasil (André da Rocha e Bagual) e a cv. Pensacola. O delineamento experimental utilizado foi o de blocos casualizados em esquema fatorial $4 \times 9$, com quatro repetições de campo. A partir da variabilidade de respostas encontradas para os caracteres agronômicos são indicados a prosseguir no programa de melhoramento genético os genótipos $48 \mathrm{~N}$, André da Rocha e Bagual por atingirem as máximas eficiências produtivas de acordo com as doses de $\mathrm{N}$ testadas.O genótipo $36 \mathrm{~N}$ que obteve a maior eficiência de utilização 
de nitrogênio, demonstrando-se biologicamente viável com a menor dose de $\mathrm{N}$, equivalente a $60 \mathrm{~kg}$ de $\mathrm{N} \mathrm{ha}^{-1}$.

Palavras-chave: espécie nativa, fertilização nitrogenada, gênero Paspalum 


\section{INTRODUCTION}

Species of the genus Paspalum are the main constituents of natural pastures in the tropical and subtropical regions of South America (Sartor et al., 2011). In southern Brazil, these species predominate in the physiognomy and are critical for livestock production in the natural fields of the Pampa Biome. Studies have demonstrated the forage potential of different Paspalum species (Pereira et al., 2012; Motta et al., 2017; Steiner et al., 2017).

Among Paspalum species, P. notatum Flüggeis salient, with native genotypes of recognized forage potential, which surpasses that of the commercial cultivar Pensacola predominantly used in the southern region of the country (Fachinetto et al., 2012, Weiler et al., 2018).Knowledge of the productive potential of promising genotypes released as new cultivars coupled with the appropriate use of input technologies can be used to intensify livestock production systems. In this sense, the use of nitrogen $(\mathrm{N})$ is one of the main factors responsible for increased biomass production in natural ecosystems and is an important agronomic tool to improve the performance of warm season grasses. In natural pasture areas of the Pampa Biome, where $P$. notatum is one of the predominant species, a positive biological and economic response was observed with application of up to 200 $\mathrm{kg} \mathrm{N} \mathrm{ha}^{-1}$ (Santos et al., 2008).

On the other hand, the high cost of $\mathrm{N}$ fertilization has hindered efforts to increase production on small farms, especially in marginal cultivation regions (Do Vale et al., 2012). In developed countries, where larger amounts of $\mathrm{N}$ are applied to soils, environmental problems occur owing to its high pollutant potential (Ahlgren et al., 2008).

Among the future challenges of ruminant production is reduction in the use of non-renewable resources through the development of more productive and sustainable livestock. In order to achieve this goal, it is essential to develop forage cultivars adapted to various soil and climate conditions, with higher biomass production and efficient use of fertilizers. Therefore, the evaluation of different $P$. notatum Flügge genotypes in response to different $\mathrm{N}$ fertilization levels should be performed within a forage breeding program. Obtaining more productive genotypes with more efficient Nuse will enable more profitable and sustainable livestock production.

The aim of this study was to evaluate the influence of different levels of $\mathrm{N}$ fertilization on agronomic traits and $\mathrm{N}$ use efficiency of superior $P$. notatum Flügge genotypes.

\section{MATERIAL AND METHODS}

The experiment was conducted at the Agronomic Experimental Station belonging to the Federal University of Rio Grande do Sul. The climate is humid subtropical (Cfa), according to the Köppen classification (Moreno, 1961).During the experimental period, precipitation was $649.8 \mathrm{~mm}$ (accumulated in 5 months) in the first productive cycle and $1429.5 \mathrm{~mm}$ (accumulated in 11 months) in the second cycle, and the average temperature was $19.4{ }^{\circ} \mathrm{C}$ and $22.4{ }^{\circ} \mathrm{C}$, respectively.

The soil is classified as Typical Dystrophic Red Argisol (Embrapa, 2013).According to the Soil Chemistry and Fertility Commission (CQFS) - RS / SC (2004), soil samples for forage 
cultivation were collected at $0-10 \mathrm{~cm}$ depth and had the following chemical: characteristics: clay $=15 \% ; \mathrm{pH}\left(\mathrm{H}_{2} \mathrm{O}\right)=$ 5.4; $\mathrm{SMP}$ index $=6.3 ; \mathrm{P}\left(\mathrm{mg} \mathrm{dm}^{-3}\right)=$ 15.6; $\mathrm{K}\left(\mathrm{mg} \mathrm{dm}^{-3}\right)=151.4$; M.O. $=$ $2.7 \%$.The area was fertilized at the time of seeding with phosphorus and potassium, according to the technical indications for warm season perennial grasses, following the recommendations of CQFS (2004).

In the fall of 2011, clones of the genotypes were generated and kept in $1 \mathrm{~L}$ pots with commercial substrate in a greenhouse. Subsequently, the seedlings were transplanted to the field on $10 / 12 / 2011$ as plots formed by five rows of $1.5 \mathrm{~m}$ in length, spaced $0.15 \mathrm{~m}$ apart, totaling 50 plants per plot. The experimental design was a randomized block design in a $4 \times 9$ factorial scheme, with four field replications. The $\mathrm{N}$ fertilization treatments included four levels equivalent to $0,60,180$ and 360 $\mathrm{kg} \mathrm{N} \mathrm{ha}^{-1}$, and nine $P$. notatum genotypes $(30 \mathrm{~N}, 36 \mathrm{~N}, 48 \mathrm{~N}, 70 \mathrm{~N}, 83 \mathrm{~N}$, 95N, André da Rocha, Bagual, and cultivar Pensacola) were tested. Genotypes 30N, 36N, 48N, 70N, 83N, and $95 \mathrm{~N}$ were obtained from the United States Department of Agriculture (USDA) and derived from collections conducted in South America. In addition, the native genotypes André da Rocha and Bagual (collected in 1980 in the state of Rio Grande do Sul, Brazil) and cultivar Pensacola were used as witnesses

(Table 1).

Table 1 Identification of Paspalum notatum genotypes

\begin{tabular}{ccc}
\hline Genotypes & Identification & Ploidylevel \\
\hline $30 \mathrm{~N}$ & Santa Fé - Argentina & Tetraploid \\
$36 \mathrm{~N}$ & Santa Fé - Argentina & Tetraploid \\
$48 \mathrm{~N}$ & Mercedes - Argentina & Tetraploid \\
$70 \mathrm{~N}$ & Cordoba - Argentina & Tetraploid \\
$83 \mathrm{~N}$ & Corrientes - Argentina & Tetraploid \\
$95 \mathrm{~N}$ & Corrientes - Argentina & Tetraploid \\
V4 & Barra do Quaraí/RS - Brazil & Tetraploid \\
André da Rocha & André da Rocha/RS - Brazil & Tetraploid \\
Bagual & Missões/RS - Brazil & Tetraploid \\
Pensacola & Viamão/RS - Brazil & Diploid \\
\hline
\end{tabular}

$\mathrm{N}$ was applied as urea and fractionated in three applications per production cycle. In the first production cycle, the applications were performed on 02/24, 03/16, and 04/26/2012.In the second cycle, applications occurred on 10/24, 11/12, and 12/11/2012.All genotypes were selected in the preliminary evaluation of forage production (Fachinetto et al., 2012). The evaluation was performed by cuts, using two squares of $0.25 \mathrm{~m}^{2}$ per plot.

The cuts were performed whenever the majority of genotypes reached $20 \mathrm{~cm}$ of canopy height, such that the post-cut residue height was $5 \mathrm{~cm}$. Seven cuts were made during the evaluation period (03/16, 04/26, 11/12, and 12/11/2012; $01 / 22,02 / 20$, and 03/18/2013). After the cuts, the samples were transported to the laboratory for morphological separation of leaf blades, stems, and stems and inflorescences. Subsequently, the samples were placed in a forced air oven at $65^{\circ} \mathrm{C}$ until a constant mass was achieved. 
The measured variables included accumulated total dry mass production (TDMP, kg ha ${ }^{-1}$ ), accumulated leaf blade dry mass production (LBDMP, $\mathrm{kg}$ $\left.\mathrm{ha}^{-1}\right)$, and accumulated stem dry mass production (SDMP, $\mathrm{kg} \mathrm{ha}^{-1}$ ). The leaf: stem ratio (LSR) was calculated by the ratio between LBDMP and SDMP. Nitrogen use efficiency (NUE, $\mathrm{kg}$ of MS $\mathrm{kg}^{-1}$ of $\mathrm{N}$ applied) was calculated according to the following equation: NUE $=($ TDMP in $\mathrm{N}$ fertilized plot TDMP in unfertilized plot) / (applied N level) (Marriott; Haystead, 1993; Silveira et al., 2013).

Data were subjected to analysis of variance and the $\mathrm{F}$ test at $5 \%$ probability. When differences between treatments were detected, comparison of means was performed by the ScottKnott test at $5 \%$ probability. In addition, the variables were subjected to Pearson correlation analysis. For $\mathrm{N}$ fertilization levels, regression analysis was performed. Data were evaluated using the GENES statistical package (Cruz, 2007).

\section{RESULTS AND DISCUSSION}

The Paspalum genotypes and $\mathrm{N}$ levels were correlated $(\mathrm{p}<0.05)$ for the TDMP, LBDMP, LSR, and NUE variables. The TDMP and LBDMP parameters fit linear and quadratic regression models (Figure 1).

For TDMP, genotypes 30N, 36N, 70N, $83 \mathrm{~N}$, and $95 \mathrm{~N}$ fit the linear regression model. The results indicated that these $P$. notatum genotypes responded positively up to the maximum $\mathrm{N}$ level tested $\left(360 \quad \mathrm{Kg} \quad \mathrm{N} \quad \mathrm{ha}^{-1}\right)$ and demonstrated that the soil $\mathrm{N}$ supply did not meet the needs of the genotypes.

For each $\mathrm{kg}$ of $\mathrm{N}$ applied, there was a conversion of 11.6, 7.8, 23.4, 12.0, and $16.2 \mathrm{~kg}$ TDMP for genotypes $30 \mathrm{~N}, 36 \mathrm{~N}$, $70 \mathrm{~N}, 83 \mathrm{~N}$, and $95 \mathrm{~N}$, respectively. Although the maximum TDMP was not reached, the $70 \mathrm{~N}$ genotype exhibited the best conversion to TDMP with the tested $\mathrm{N}$ levels. 

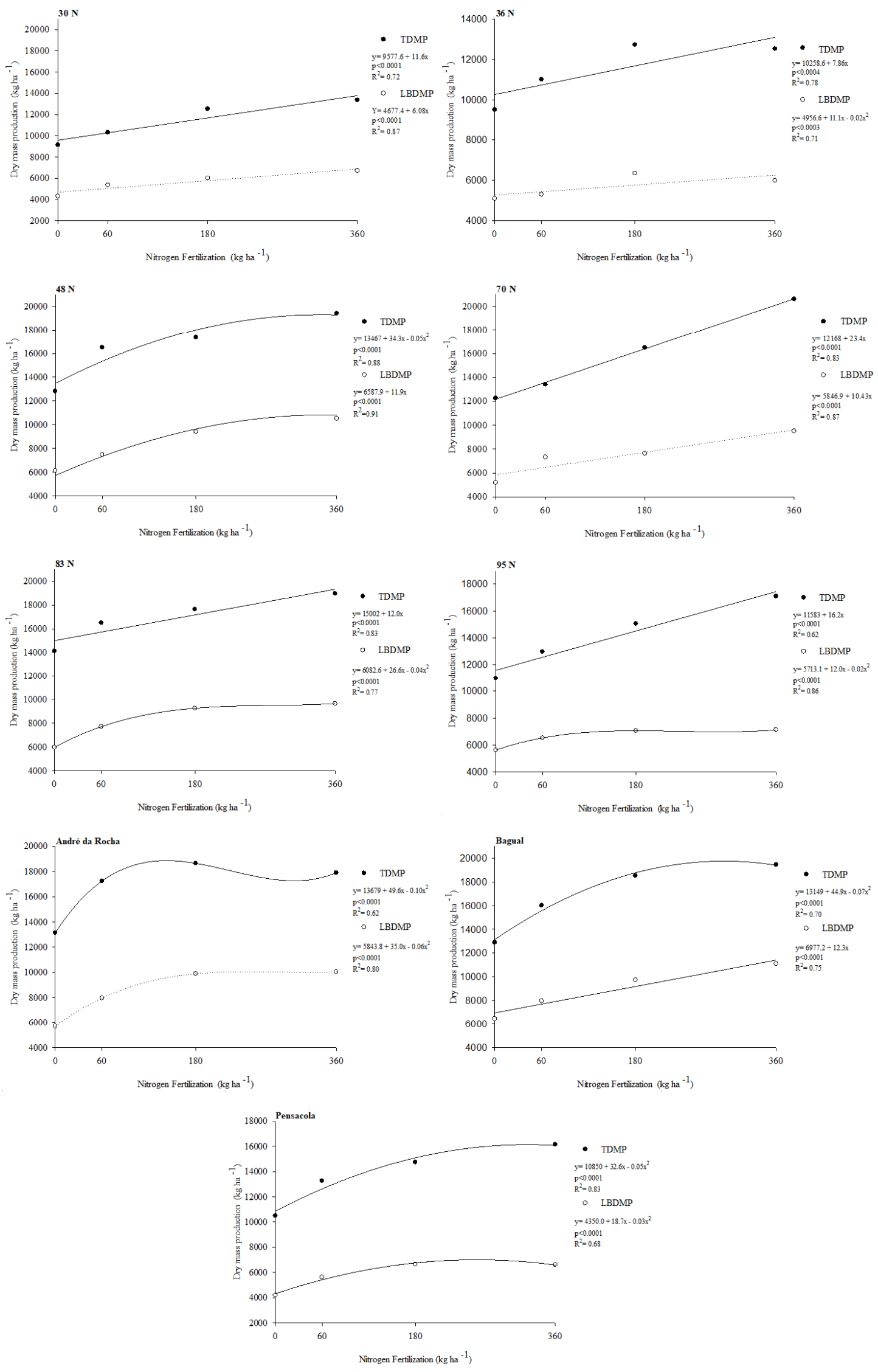
Figure 1 Total accumulated dry mass production and leaf blades of $P$. notatum genotypes treated with different levels of nitrogen fertilization.

Genotypes 48N, André da Rocha, Bagual, and cultivar Pensacola fit the TDMP quadratic regression model (Figure 1), reaching the maxima with the $\mathrm{N}$ levels tested. The highest and lowest TDMP corresponded to the Bagual (20.349 kg DM ha ${ }^{-1}$ ) and $48 \mathrm{~N}$ (19.347 kg DM ha ${ }^{-1}$ ) genotypes when 320 and $350 \mathrm{~kg} \mathrm{~N}^{-1}$ were applied, respectively.
In this context, the André da Rocha genotype, which had a TDMP of 19.829 kg DM ha ${ }^{-1}$ using $250 \mathrm{~kg} \mathrm{~N} \mathrm{ha}^{-1}$, was remarkable. On the other hand, Pensacola only reached the maximum TDMP (16.163 kg DM ha ${ }^{-1}$ ) when 330 $\mathrm{kg} \mathrm{N}$ ha $^{-1}$ was applied, and this TDMP was lower than the maximum achieved by genotypes $48 \mathrm{~N}$, André da Rocha, and Bagual (Table 2).

Table 2 Maximum yield efficiency of Paspalum notatum genotypes according to nitrogen fertilization

\begin{tabular}{ccccc}
\hline & \multicolumn{4}{c}{ Maximum productive efficiency $\left(\mathrm{kg} \mathrm{ha}^{-1}\right)$} \\
\cline { 2 - 5 } Genotypes & TDMP & Nitrogen levels & LBDMP & Nitrogen levels \\
\hline $30 \mathrm{~N}$ & $13.354^{*}$ & 360 & $6.698^{*}$ & 360 \\
$36 \mathrm{~N}$ & $12.520^{*}$ & 360 & 6.496 & 270 \\
$48 \mathrm{~N}$ & 19.347 & 350 & $10.520^{*}$ & 360 \\
$70 \mathrm{~N}$ & $20.602^{*}$ & 360 & $9.512^{*}$ & 360 \\
$83 \mathrm{~N}$ & $18.964^{*}$ & 360 & 10.505 & 330 \\
95N & $17.098^{*}$ & 360 & 7.513 & 300 \\
André da Rocha & 19.829 & 250 & 10.948 & 290 \\
Bagual & 20.349 & 320 & $11.100^{*}$ & 360 \\
Pensacola & 16.163 & 330 & 7.264 & 310 \\
\hline
\end{tabular}

TDMP $=$ accumulated total dry mass production. LBDMP $=$ accumulated dry leaf blade mass production *TDMP and LBDMP can be overcome by applying $\mathrm{N}$ doses greater than $360 \mathrm{~kg} \mathrm{~N} \mathrm{ha}^{-1}$.

Studies have shown that the cultivar Pensacola has lower performance than native (Fachinetto et al., 2012; Graminho et al., 2017) and P. notatum hybrids (Weiler et al., 2018). The results here suggested that the $48 \mathrm{~N}$, André da Rocha, and Bagual genotypes may be used for future hybridization for development of superior genotypes. In addition, notably, the $70 \mathrm{~N}$ and $83 \mathrm{~N}$ genotypes did not reach the maximum TDMP with the $\mathrm{N}$ doses tested but showed high TDMP, suggesting the need for further studies with these genotypes, including with different $\mathrm{N}$ sources and edaphoclimatic conditions.
When superior genotypes are obtained with respect to the traits of interest of the breeding program, such as TDMP and LBDMP, they can be launched as new cultivars; as $P$. notatum are an apomitic species, the characteristics of the obtained hybrids will be fixed in F1 (Acuna et al., 2009).In a study conducted with $P$. notatum, Silveira et al. (2013) observed increases in forage production of $25 \%$ to $50 \%$ when 60 and

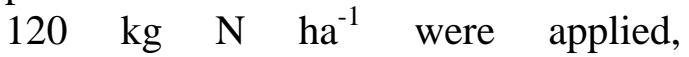
respectively. Scheffer-Basso et al. (2010), who evaluated P.pauciliatum exposed to different levels of $\mathrm{N}$, observed positive responses of variable forage dry mass production to the 
application. According to Santos et al. (2008), the application of $\mathrm{N}$ in natural pastures belonging to the Pampa Biome is economically viable up to $200 \mathrm{~kg}$ of $\mathrm{N}$ ha $^{-1}$ from both a biological and economic point of view.

For the LBDMP variable, the $30 \mathrm{~N}, 48 \mathrm{~N}$, $70 \mathrm{~N}$ and Bagual genotypes fit the linear regression model. For each $\mathrm{kg}$ of $\mathrm{N}$ applied, there was a conversion of 6.1, $11.9,10.4$ and $12.3 \mathrm{~kg}$ of LBDMP, respectively. Genotypes 36N, 83N, 95N, André da Rocha, and cultivar Pensacola fit the LBDMP quadratic regression model (Figure 1), reaching the maxima within the $\mathrm{N}$ levels tested. The highest and lowest LBDMP corresponded to the André da Rocha $\left(10.948 \mathrm{~kg} \mathrm{DM} \mathrm{ha}^{-1}\right)$ and 36N $(6.496 \mathrm{~kg}$ $\mathrm{DM} \mathrm{ha}^{-1}$ ) genotypes when 290 and 270 $\mathrm{N} \mathrm{ha}^{-1}$ were applied, respectively.

As the genotype André da Rocha and cultivar Pensacola required adjustments to the quadratic regression model for the TDMP and LBDMP variables, it was possible to calculate the percentage of LBDMP present in the TDMP. LBDMP values of $55.2 \%$ and $44.9 \%$ in the TDMP were obtained for André da Rocha and cultivar Pensacola, respectively. The highest nutritional quality of forage plants is in the leaf blades, which is the structure preferred by grazing animals (Bratti et al., 2009).Thus, the highest proportion of leaf blades is one of the main criterion for genotype selection in forage breeding programs.

There was a positive correlation between TDMP and LBDMP ( $r=0.99$; $\mathrm{p}<0.0001)$, confirming the positive increments obtained between the variables. The high correlation between the variables described above was also observed in Brachiaria ruziziensis S. genotypes (Borges et al., 2011) and $P$. notatum genotypes and hybrids (Weiler et al., 2018). This result is particularly important, because selecting genotypes for high TDMP will result in selection of genotypes with high LBDMP. Pereira et al. (2012), who evaluated genetic variability in the genus Paspalum, emphasized that TDMP and LBDMP were the most effective traits for identifying genotypes with higher forage traits. Thus, the selection of genotypes with higher TDMP remains, in general, the main focus in forage breeding programs. Moreover, the high correlation between TDMP and LBDMP suggested that the laborious task of separating morphological components, at least in this species, could be avoided, saving time and resources.

The applied $\mathrm{N}$ levels had the lowest influence on the LSR variable. Most genotypes did not show increased LSR with increasing $\mathrm{N}$ fertilization levels, except for genotypes $83 \mathrm{~N}$ and André da Rocha, which presented responses to the level equivalent to $60 \mathrm{~kg} \mathrm{~N}^{-1}$ (Table 3).Selection for reduced stem production and increased leaf production has been strongly advocated for forage breeding (Pereira et al., 2011). In the present study, notably, the LSR of cultivar Pensacola remained at 0.9 without $\mathrm{N}$ fertilization. A high LSR is desired in forage plants as it confers better grazing adaptation or tolerance to mowing because it presents a phenological moment when apical meristems are closer to the ground and therefore less vulnerable to grazing elimination (Silva et al., 2013).

Table 3 Leaf: stem ratio Paspalum notatum genotypes in response to different of nitrogen fertilization 


\begin{tabular}{ccccc}
\hline \multirow{2}{*}{ Genotypes } & \multicolumn{4}{c}{ Nitrogen levels $\left(\mathrm{kg} \mathrm{ha}^{-1}\right)$} \\
\cline { 2 - 5 } & 0 & 60 & 180 & 360 \\
\cline { 2 - 5 } $30 \mathrm{~N}$ & $1.25 \mathrm{Ab}$ & $1.21 \mathrm{Aa}$ & $1.38 \mathrm{Aa}$ & $1.26 \mathrm{Ab}$ \\
$36 \mathrm{~N}$ & $1.34 \mathrm{Aa}$ & $1.36 \mathrm{Aa}$ & $1.29 \mathrm{Ab}$ & $1.19 \mathrm{Ab}$ \\
$48 \mathrm{~N}$ & $1.29 \mathrm{Ab}$ & $1.27 \mathrm{Aa}$ & $1.43 \mathrm{Aa}$ & $1.45 \mathrm{Aa}$ \\
$70 \mathrm{~N}$ & $1.17 \mathrm{Ab}$ & $1.35 \mathrm{Aa}$ & $1.18 \mathrm{Ab}$ & $1.38 \mathrm{Aa}$ \\
$83 \mathrm{~N}$ & $1.15 \mathrm{Bb}$ & $1.46 \mathrm{Aa}$ & $1.47 \mathrm{Aa}$ & $1.35 \mathrm{Aa}$ \\
$95 \mathrm{~N}$ & $1.53 \mathrm{Aa}$ & $1.45 \mathrm{Aa}$ & $1.45 \mathrm{Aa}$ & $1.27 \mathrm{Ab}$ \\
André da Rocha & $1.02 \mathrm{Bb}$ & $1.39 \mathrm{Aa}$ & $1.59 \mathrm{Aa}$ & $1.48 \mathrm{Aa}$ \\
Bagual & $1.56 \mathrm{Aa}$ & $1.57 \mathrm{Aa}$ & $1.55 \mathrm{Aa}$ & $1.56 \mathrm{Aa}$ \\
Pensacola & $0.92 \mathrm{Ab}$ & $1.19 \mathrm{Aa}$ & $1.17 \mathrm{Ab}$ & $1.08 \mathrm{Ab}$ \\
\hline
\end{tabular}

Means followed by different uppercase letters are significantly diferente within a row, and means followed by different lowercase letters are significantly diferente within a column based on the ScottKnott 5\% mean test.

$\mathrm{LSR}=$ leaf: stem ratio.

For the NUE variable, the highest value observed at the level equivalent to
$60 \mathrm{~kg}$ of $\mathrm{N}$ ha-1, decreasing with increasing $\mathrm{N}$ levels applied (Table 4).

Table 4 Nitrogen utilization efficiency of different Paspalum notatum genotypes

\begin{tabular}{cccc}
\hline \multirow{2}{*}{ Genotypes } & \multicolumn{3}{c}{ NUE (kg of DM kg de N applied) } \\
\cline { 2 - 4 } & \multicolumn{3}{c}{ Nitrogen levels $\left(\mathrm{kg} \mathrm{ha}^{-1}\right)$} \\
\cline { 2 - 4 } $30 \mathrm{~N}$ & $9.8 \mathrm{Ac}$ & $9.4 \mathrm{Bb}$ & 360 \\
$36 \mathrm{~N}$ & $69.0 \mathrm{Aa}$ & $27.8 \mathrm{Ba}$ & $13.6 \mathrm{Cc}$ \\
$48 \mathrm{~N}$ & $30.6 \mathrm{Ab}$ & $12.6 \mathrm{Bb}$ & $9.1 \mathrm{Cb}$ \\
$70 \mathrm{~N}$ & $16.6 \mathrm{Ac}$ & $11.7 \mathrm{Bb}$ & $11.5 \mathrm{Bb}$ \\
$83 \mathrm{~N}$ & $19.8 \mathrm{Ac}$ & $13.4 \mathrm{Bb}$ & $6.7 \mathrm{Cc}$ \\
$95 \mathrm{~N}$ & $16.7 \mathrm{Ac}$ & $11.3 \mathrm{Bb}$ & $8.5 \mathrm{Cc}$ \\
André da Rocha & $34.1 \mathrm{Ab}$ & $15.2 \mathrm{Bb}$ & $6.6 \mathrm{Cc}$ \\
Bagual & $36.2 \mathrm{Ab}$ & $15.5 \mathrm{Bb}$ & $9.1 \mathrm{Cb}$ \\
Pensacola & $23.0 \mathrm{Ab}$ & $11.7 \mathrm{Bb}$ & $7.8 \mathrm{Cc}$
\end{tabular}

Means followed by different uppercase letters are significantly diferente within a row, and means followed by different lowercase letters are significantly diferente within a column based on the ScottKnott $5 \%$ mean test.

NUE: nitrogen utilization efficiency.

The 36N genotype presented the highest NUE when $\mathrm{N}$ was applied at $60 \mathrm{~kg} \mathrm{~N} \mathrm{ha}{ }^{-1}$, but $60 \%$ and $80 \%$ reductions were observed for the levels equivalent to 180 and $360 \mathrm{~kg} \mathrm{~N} \mathrm{ha}{ }^{-1}$, respectively. Obour et al. (2017), who evaluated Panicum virgatum L. at increasing levels of $\mathrm{N}$ fertilization $(0$, 45, 90, 135, and $180 \mathrm{~kg} \mathrm{~N} \mathrm{ha}{ }^{-1}$ ), observed a linear reduction in NUE. The reduction in efficiency can be explained by the reduced capacity of the plant to absorb and use the nutrient for production, as well as possible soil leaching.

$\mathrm{N}$ is one of the most difficult nutrients to manage effectively. In many agroecological systems, a substantial 
portion of applied $\mathrm{N}$ is lost from soil to groundwater, rivers, and oceans (Glass, 2003), because plants convert only $30 \%$ to $40 \%$ of the applied $\mathrm{N}$ into useful products. Thus, the variability between the studied genotypes allows the selection of plants with higher genetic potential for the NUE trait. According to Seepaul et al. (2016), several factors contribute to the amount of $\mathrm{N}$ removed by plant biomass, including the genotype and amount of $\mathrm{N}$ applied.NUE has been used to describe a plant's ability to acquire and use $\mathrm{N}$ to produce biomass, and is expressed as the yield of biomass produced per unit of $\mathrm{N}$ applied (Seepaul et al., 2016).In this sense, including this information as a tool for selecting genotypes of this species in forage breeding programs is important. Indirect calculation of NUE has been widely used owing to its practicality and low cost (Silveira et al., 2013; Obour et al., 2017). The most commonly used source of $\mathrm{N}$ in Brazil is urea; however, research data indicate volatilization losses of up to $30 \%$ of N. Measures that increase the NUE should be implemented in order to promote the management of an economically sustainable, forage quality production system with minimal negative environmental impact.

The results of this study showed that $\mathrm{N}$ fertilization influences the agronomic traits of different genotypes, increasing biomass production. The use of NUE as a selection criterion may help the breeder obtain plants with higher forage yields with lower $\mathrm{N}$ levels. This may favor more profitable and sustainable livestock farming owing to reduced spending on $\mathrm{N}$ fertilizer and reduced impacts on the environment, such as the use of non-renewable fossil fuel reserves, effects on global warming, and water contamination.
The results of this work indicated that the evaluation and selection of native genotypes may produce new cultivars that are more productive and use $\mathrm{N}$ more efficiently than currently available genotypes on the market, such as $P$. notatum 'Pensacola'. Thus, based on the variability observed in the evaluated agronomic traits, the $48 \mathrm{~N}$, André da Rocha, and Bagual genotypes were indicated to be promising for continued use in the breeding program because they reached the maximum productivity efficiencies according to the $\mathrm{N}$ rates tested. The $70 \mathrm{~N}$ and $83 \mathrm{~N}$ genotypes are also indicated for new evaluations, because they showed ability to express forage yields with higher $\mathrm{N}$ rates than those tested in the present study, which may indicate their applicability in intensive livestock systems. The 36N genotype had the highest $\mathrm{N}$ use efficiency, proving to be biologically viable with the equivalent of $60 \mathrm{~kg} \mathrm{~N} \mathrm{ha}^{-1}$.

These genotypes could be introduced in rural areas to recover degraded natural pastures or directly as cultivated pastures, with higher forage production due to positive responses to $\mathrm{N}$ application. In addition, this introduction could reduce the use of exotic species and preserve the natural ecosystem, as $P$. notatumis native to this environment and better studied; thus, more information on $P$. notatum management practices is available.

\section{ACKNOWLEDGE}

We would like to thank Conselho Nacional de Desenvolvimento Científico e Tecnológico (CNPq), Coordenação de Aperfeiçoamento de Pessoal de Nível Superior (CAPES), and Sul Pasto for the financial support. 


\section{REFERENCES}

ACUÑA, C.A.; BLOUNT, A.R.;

QUESENBERRY, K.H.;

KENWORTHY, K.E.; HANNA, W.W.

Bahiagrass tetraploid germplasm:

reproductive and agronomic

characterization of segregating progeny.

Crop Science, v.49, n.2, p.581-588, 2009.

AHLGREN, S.; BAKY, A.;

BERNESSON, S.; NORDBERG, A.;

NORÉN, O.P.; HANSSON, A.

Ammonium nitrate fertilizer production

based on biomass - environmental

effects from a life cycle perspective.

Bioresource Technology, v.99, n.17, p.8034-8041, 2008.

BORGES, V.; SOBRINHO, F.S.; LÉDO, F.J. da S.; KOPP, M.M.

Association between traits and path analysis in half-sib progeny selection of Brachiaria ruziziensis. Revista Ceres, v.58, n.6, p.765-772, 2011.

BRATTI, L.F.S.; DITTRICH, J.R.; BARROS, C.S. de.; SILVA, C.J.A. da.; MONTEIRO, A.L.G.; ROCHA, C. da.; ROCHA, F.M.P. da. Comportamento ingestivo de caprinos em pastagem de azevém e aveia-preta em cultivo puro e consorciado. Ciência Animal

Brasileira, v.10, n.2, p.397-405, 2009.

COMISSÃO DE QUÍMICA E

FERTILIDADE DO SOLO RS/SC (CQFS RS/SC). 2004. Manual de adubação e calagem para estados do Rio Grande do Sul e Santa Catarina. SBCS/ NRS. 10. ed. Porto Alegre, 400 p.

CRUZ, C.D. Programa GENES: Aplicativo computacional em genética e estatística. 2007. 442p.

DO VALE, J.C.; FRITSCHE-NETO, R.; BERMUDEZ, F.; MIRANDA, G.V. Herança e correlação entre caracteres associados à eficiência de uso de nitrogênio em milho tropical. Pesquisa Agropecuária Brasileira, v.47, n.3, p.385-392, 2012.

EMPRESA BRASILEIRA DE PESQUISA AGROPECUÁRIA EMBRAPA. Centro Nacional de Pesquisa do Solo. CNPS. 3 ed.Sistema Brasileiro de Classificação de Solos. Rio de Janeiro: Embrapa 2013. 342p.

FACHINETTO, J.M.; SCHNEIDER, R.; HUBBER, K.G. da C.;

DALL'AGNOL, M. Avaliação agronômica e análise da persistência em uma coleção de acessos de Paspalum notatumFlügge (Poaceae). Revista Brasileira de Ciências Agrárias, v.7, n.1, p.189-195, 2012.

GLASS, A.D.M. Nitrogen Use Efficiency of Crop Plants: Physiological Constraints upon Nitrogen Absorption. Critical Reviews in Plant Sciences, v.22, n.5, p.453-470, 2003.

GRAMINHO, L.A.; DALLAGNOL, M.; POTTER, L.; LOPES, R.R.; SIMIONI, C.; WEILER, R.L. Forage characters of different Paspalum species in Rio Grande do Sul: a meta-analysis. Ciência Rural, v.47, n.7, p.1-7, 2017.

MARRIOTT, C. A.; HAYSTEAD, A. Nitrogen fixation and transfer. In: DAVIES, A.; BAKER, R.D.; GRANT, S.A.; LAIDLAW, A.S. (eds.) Sward measurement handbook. 2. Ed. London: British Grassland Society. Grassland Research Institute, 1993. p.245-264. 
MORENO, J.A. Clima do Rio Grande do Sul. Porto Alegre: Secretaria da Agricultura, 1961. 41p.

MOTTA, E.A.M., DALL'AGNOL, M.; PEREIRA, E.A.; MACHADO, J.M.; SIMIONI, C. Valor forrageiro de híbridos interespecíficos superiores de Paspalum.Revista Ciência

Agronômica, v.48, n.1, p. 191-198, 2017.

OBOUR, A.K.; HARMONEY, K.; HOLMAN, J.D. Nitrogen fertilizer application effects on Switchgrass herbage mass, nutritive value and nutrient removal. Crop Science, v.57, n.3, p.1754-1763, 2017.

PEREIRA, E.A.;DALL'AGNOL, M.; NABINGER, C.; HUBER, K.G.C.; MONTARDO, D.P.; GENRO, T.C.M. Produção agronômica de uma coleção de acessos de Paspalum nicorae Parodi. Revista Brasileira de Zootecnia, v.40, n.3, p.498-508, 2011.

PEREIRA, E.A.; BARROS, T.; VOLKMANN, G.K.; BATTISTI, J.A.G. da S.; SIMIONI, C.;

DALL'AGNOL, M. Variabilidade genética de caracteres forrageiros em Paspalum. Pesquisa Agropecuária Brasileira, v.47, n.10, p.1533-1540, 2012.

SANTOS, D.T.; CARVALHO, P.C.F.; NABINGER, C.; CARASSAI, I.J.; GOMES, L.H. Eficiência bioeconômica da adubação de pastagem natural no sul do Brasil. Ciência Rural, v.38, n.2, p.437-444, 2008.

SARTOR, M.E.; QUARIN, C.L.; URBANI, M.H.; ESPINOZA, F. Ploidy levels and reproductive behaviour in natural populations of five Paspalum species. Plant Systematics and Evolution, v.293, n.1, p.31-41, 2011.

SCHEFFER-BASSO, S.M.; FAVERO, F.; CESARO, E. P. de.; JOURIS, C.; ESCOSTEGUY, P.A.V. Preliminary evaluation of Paspalum pauciciliatum: seasonal production and nitrogen response. ARS Veterinária, v.26, n.1, p.53-59, 2010.

SEEPAUL, R.; BISOONDAT, M.; REDDY, K.R.; EVANS, W.B. Nitrogen Application Rate and Genotype Effects on Switchgrass Production and Chemical Characteristics. American Journal of Plant Sciences, v.7, p.533546, 2016.

SILVA, D.R.G.; COSTA, K.A.P.; FAQUIN, V.; OLIVEIRA, I.P.; BERNANRDES, T.F. Doses e fontes de nitrogênio na recuperação das características estruturais e produtivas do capim - marandu. Revista Ciência Agronômica, v.44, n.1, p.184-191, 2013.

SILVEIRA, M.L.; VENDRAMINI, J.M.B.; SELLERS, B.; MONTEIRO, F.A.; ARTUR, A.G.; DUPAS, E. Bahia grass response and $\mathrm{N}$ loss from selected $\mathrm{N}$ fertilizer sources. Grass Forage Science, v.70, n.1, p.154-160, 2013.

STEINER, M.G.; DALL'AGNOL, M.; NABINGER, C.; SCHEFFER-BASSO, S.M.; WEILER, R.L.; SIMIONI, C.; SCHIFINO-WITTMANN, M.T.; MOTTA, E.A.M. Forage potential of native ecotypes of Paspalum notatum and $P$. guenoarum. Anais da Academia Brasileira de Ciências, v.89, p. 17531760, 2017. 
WEILER, R.L; DALL'AGNOL, M.;

SIMIONI, C.; KRYCKI, K.C.;

PEREIRA, E.A.; MACHADO, J.M.;

MOTTA, E.A.M. Intraspecific

tetraploid hybrids of Paspalum notatum:

agronomic evaluation of segregating progeny. Scientia Agricola, v.75, n.1, p. 36-42, 2018. 